\title{
DEVELOPING E-LEARNING BY USING KELASE IN BIOLOGY SUBJECT FOR XI GRADE IN SMA NEGERI 1 SEMARAPURA
}

\author{
Desak Putu Parmiti1 ${ }^{*}$, Ni Putu Leoni Susiliastana Dewi ${ }^{2}$ \\ 1 Jurusan Teknologi Pendidikan, Universitas Pendidikan Ganesha \\ 2 Jurusan Teknologi Pendidikan, Universitas Pendidikan Ganesha
}

\begin{abstract}
Abstrak
The problem found at SMA Negeri 1 Semarapura was that the learning achievement in Biology was not yet satisfactory. This study was aimed at (1) describing the design of E-learning development, (2) describing the E-learning design quality validation result according to the expert judges and the product try out result, (3) finding out the effectiveness of E-learning developed. This study was research and development. It used Hannafin and Peck's model. The data which were collected in this study were qualitative and quantitative data. The data were collected through document recording, questionnaire and test. The results were as follows, (1) the E-learning design for Biology subject using Hannafin and Peck's model which covered three stages, (2) the E-learning for Biology subject that was developed was valid; (a) the result of content experts' judgment about the content of the subject shows that the Elearning falls into very good qualification (91.4\%), (b) the result of the E-learning experts' judgment of the E-learning design shows that E-learning falls into good qualification (90.06\%), (c) the result of instructional design experts' judgment about the E-learning falls into good qualification (89.02\%), (d) the result of individual try out, small group try out, and field try out show that E-learning falls into good qualification (89.93\%), (89.34\%), and (83.03\%), (3) the effectiveness of the development shows that E-learning that was developed was effective in enhancing Biology learning achievement $\left(t_{\text {obs. }}=25.89>t_{\text {c.v. }}=2.390\right.$, at the $5 \%$ level of significance). That means that E-learning has proven to be effective in enhancing Biology learning achievement significantly.
\end{abstract}

\author{
Keywords: \\ E-learning, Hannafin \& \\ Peck, development
}

\section{PENDAHULUAN}

Biology is a course that prepares the students with various abilities about how to know and understand concepts and facts deeply. Since the number of concepts and skills that have to be acquired by the students through class meetings are not supported by the limited time, in which a period is less than the time needed, then, there is a need for a system and media to conduct the course which enables the acquisition of knowledge and skills by the students.

Based on the observation and interview result with Biology teachers who teach grade XI at SMAN 1 Semarapura, teachers tend to use lecturing rather than instructional media, so that the students tend to ignore and do not pay attention to the materials taught by the teachers. Furthermore, the use of teaching media was too monotonous that made the students lazy to learn, then the limited period in which there were only 2 class meetings in a week, each last thing $2 \times 45$ minutes, which makes the teaching less optimal.

With advances in technology, teachers are expected to develop teaching by using ICT, so that teaching can be more meaningful for students both at the time of class meeting at school and outside of school individually. One of the developments in technology is the use of e-learning.

With e-learning it is expected that students can be helped in learning, so that they can communicate directly and indirectly both in the class meeting and outside. Based on the description above, this study tried to develop e-learning by using Kelase for Biology at grade XI in SMAN 1 Semarapura.

In line with the description above, the problems in this study can be formulated as follows: (1) what is the design of e-learning development in Biology for grade XI in SMAN 1 Semarapura, (2) how good is the quality of the validation of e-learning develop according to the experts and the product try out in 
Biology for grade XI in at SMAN 1 Semarapura, and (3) how effective is the e-learning develop to improve learning achievement in Biology for the students of grade XI in SMAN 1 Semarapura.

Based on the formulation of the problem, the aims of this study were (1) to describe the design of the development of e-learning for Biology at grade XI in SMAN 1 Semarapura, (2) to describe the quality of the validation of e-learning develop according to experts and product try out for Biology for grade XI in SMAN 1 Semarapura, (3) to test the effectiveness of e-learning develop in improving learning achievement in Biology for the students of grade XI in SMAN 1 Semarapura.

\section{METODE PENELITIAN}

In this study, the writers used Hannafin and Peck's development model (need analysis, design, development and implementation). This study used 3 methods of data collection to answer the problems about the design of e-learning development, quality of e-learning and effectiveness of e-learning, i.e. document recording, questionnaire and test. In this research and development, 3 data analysis technique were used, i.e. (1) quantitative descriptive analysis, and inferential statistical analysis (PS).

Percentage $=\frac{\Sigma(\text { Answer } \times \text { score of each option })}{n \times \text { highest score }} \times 100 \%$

(Tegeh and Kirna, 2010:101)

Note:

$\sum=$ number

$\mathrm{N}=$ number of all questionnaire items

Before doing the hypothesis testing (correlated t-test) prerequisite test were done (normality and homogeneity testing). The formula to compute prerequisite testing and hypothesis testing (correlate testing) is as follows. Normality test was done to know whether the score distribution of each variable was normal or not, for this purpose Liliefors formula could be used with the following formula.

According to Koyan (2012:109) the way to test the normality of data can be done by using Liliefors technique. If $\mathrm{L}_{0}<\mathrm{L}_{\mathrm{t}}$, then $\mathrm{H}_{0}$ is accepted, therefore it can be concluded that the sample come from population with normal distribution. This homogeneity test is done to find the level homogeneity in two ways taken from separate data groups of one sample. To test the homogeneity of variance of the sample data, Fisher (F) tested used with the following formula.

$$
F_{\text {hit }}=\frac{\text { Varians terbesar }}{\text { Varians terkecil }}
$$

(Koyan, 2012:40)

The analysis technique used to test the hypothesis was t-test. The formula for correlated t-test is as follows.

$$
t=\frac{\overline{X_{1}}-\overline{X_{2}}}{\sqrt{\frac{s_{1}^{2}}{n_{1}}+\frac{s_{2}{ }^{2}}{n_{2}}-2 r\left(\frac{s_{1}}{\sqrt{n_{1}}}\right)\left(\frac{s_{2}}{\sqrt{n_{2}}}\right)}}
$$

(Koyan, 2012:34)

\section{ANALISIS DAN PEMBAHASAN}

The were 5 points discussed in the result of the study, i.e. (1) e-learning design, (2) quality of elearning development based on the validation result, (3) product development revision, (4) data analysis prerequisite test, and (5) hypothesis testing. Need analysis was done as the initial stage in developing elearning. This stage was done through an interview with Biology teachers at SMAN 1 Semarapura, Ibu Luh Ratna Tirtawati, S.Pd., M.Pd. based on the result of the interview, it was found out that the problems faced during the teaching and learning process, was the limitation of periods for Biology, so that the teaching of the material was less optimal.

The e-learning design was done by selecting and determining the software to be used to develop elearning. In the development/ implementation of e-learning, the developer is required to apply the skills that he or she has to develop e-learning according to the design. The next stage is the stage of product 
used by users. Mahadewi (2013) states that after testing is done to all systems, the next stage is product used stage in the environment of the user himself or herself which is known as product release.

Course content expert testing. E-learning was assess by content experts who was at the same time Biology teachers at SMAN 1 Semarapura, Luh Ratna Tirtawati, S.Pd., M.Pd. based on the result of the course content expert assessment, the percentage of the level of achievement was $91.4 \%$, falling to very good qualification. Instructional design experts testing. This e- learning product was tested by an instructional design expert, Dr. I Made Tegeh, M.Pd. Based on the assessment by the instructional design expert, the level of achievement was $89.02 \%$, falling into very good qualification.

E-learning expert testing. E-learning was tested by an e-learning expert, Adrianus I Wayan Ilia Yuda Sukmana, S.Kom., M.Pd. Based on the assessment of the e-learning expert, the level of achievement was $90.06 \%$ falling into very good qualification.

Individual try out. The subjects of the individual try outs were the students of grade XI MIA 2 SMAN 1 Semarapura with the total number of 3 students with the result of percentage average $=269.87$ : $3=89.93 \%$. Percentage average $89.93 \%$ falls into very good qualification. Small group try out with 12 students with the percentage average $=1072.1: 12=89.34 \%$. This percentage average falls into very good qualification. Field try out with 40 students with the percentage average $=3350.0: 40=83.75 \%$. This percentage average falls into good qualification.

The product development revision. This e-learning product development passed through 6 stages: (1) course content experts testing, (2) e-learning experts testing, (3) instructional design experts testing, (4) individual try out, (5) small group try out, and (6) field try out. In the six stages of revision, there were some revision and some inputs as well as suggestion from expert and the subjects of the try out.

Based on the pre-test and posttest score involving 40 students, correlated sample t-test was done. The average of pre test score was 58.87 and the average of posttest score were 89.5. the increase in the students' average score could also be seen based o the answer of the students in a test most of the students answers were wrong in pretest and became correct in the posttest. Viewed from the conversion of the grade XI students' learning achievement at SMAN 1 Semarapura, their posttest average score was 89.5 falling into very good qualification. This means that e-learning media was effective in helping the students to improve their learning achievement in Biology. This was caused by the fact that e-learning could cover all the teaching and learning material and can motivate the students to learn to optimize their understanding of the teaching material.

\section{KESIMPULAN}

Based on the formulation of problem, result of data analysis and discussion, the following conclusion can be made.

First, the e-learning design develops in all stages of Hannafin and Peck's development model.

Second, the visibility of the e-learning development according to (1) instructional design experts is very good (89.02\%), (2) course content experts is very good (91.4\%), (3) e-learning expert is very good (90.06\%), (4) based on individual try out is very good (89.93\%), (5) based on small group try out (89.34\%), and (6) field try out is very good (83.75\%).

Third, e-learning was proven to be effective significantly and could improve Biology learning achievement of grade XI. The effectiveness of the product of e-learning development in teaching was measured by using pretest and posttest score of 40 students of grade XI MIA 3 in SMAN 1 Semarapura. The average score for pretest was 57.87 and for posttest was 89.5. After manual computation it was found that the $t_{o b s}$ was 25.890 . Then, the $t_{o b s .}$ was compared to $t_{c . v .}$ at $d f=n 1+n 2-2=40+40-2=78$. The $t_{c . v .}$ for $d f$ 78 are $=0.05=2.390$. Thus, $t_{\text {obs. }}$ is greater than $t_{\text {c.v. }}$ so that $\mathrm{H}_{0}$ is rejected and $\mathrm{H}_{1}$ accepted. This means that Biology e-learning media is effective in improving the students learning achievement in Biology at SMAN 1 Semarapura. follows:

Suggestion that can be made in relation to the development of e-learning can be grouped into 4 as

To the students, it is suggested to use e-learning optimally. E-learning cannot only be used at the school but it can also be used anywhere and anytime at the time the students want to learn. By using elearning maximally, it can be expected that the students' learning achievement can improve more optimally.

To the teachers, it is suggested that they used e-learning in Biology course, since by using elearning the students interest in an intention to learn can improve. It is also suggested to the teachers to develop the same type of e-learning by themselves. Since by developing e-learning according to the 
teaching that the teacher wants, it can overcome the problem of limited media, space and time in managing the teaching and learning process.

To the principal, it is suggested that the principal makes a policy to provide training for teachers in developing and using e-learning at SMAN 1 Semarapura. To the principal too, it is suggested that the principal provide supporting facilities for e-learning at school by sending a proposal to the related organization.

To other researchers, it is suggested that the result of this research can be used as reference in doing a study of the same type of e-learning for further development.

\section{DAFTAR PUSTAKA}

Agung, A.A. Gede. 2014. Metodologi Penelitian Pendidikan. Buku Ajar Metodologi Penelitian Pendidikan. Singaraja: Undiksha

Duniawan, I. G. 2014. “Integrasi TIK, E-Learning Solusi Alternatif dalam Kegiatan Pembelajaran”.Makalah disajikan dalam Seminar Problematika Teknologi Pendidikan. Jurusan Teknologi Pendidikan. Singaraja, 22 Desember 2014.

Fithri, D. L. 2014. “Analisa dan Perancangan E-Learning Pembelajaran Grammer untuk Meningkatkan Potensi Siswa".Jurnal SIMETRIS, Vol 5 No 1 April 2014 ISSN: 2252-4983.

Koyan, I Wayan. 2012. Statistik Pendidikan.Singaraja: Undiksha.

Mahadewi, Luh Putu Putrini. 2013. Pemrograman Dengan Teks. Singaraja: Undiksha

Mahadewi, Luh Putu Putrini.2016. Blended Learning DinamisasiSetingPembelajaran. Singaraja: FIP Undiksha

Mahadewi, Luh Putu Putrini dan I Kadek Edi Yudiana.2016. Pengembangan Prototype PembelajaranOnline Dengan Cognitive Load Theory Pada Mata Kuliah Strategi Pembelajaran di Fakultas Ilmu Pendidikan. (Laporan Penelitian). Singaraja: FIP Undiksha.

Rusman. 2012. Model-model Pembelajaran. Depok: PT Rajagrafindo Persada.

Tegeh, I Made dan I Made Kirna. 2010. Metode Penelitian Pengembangan Pendidikan.Buku Ajar. Singaraja: Undiksha 